\title{
Facing Uncertainty: How Small Songbirds Acquire and Use Social Information in Habitat Selection Process?
}

\author{
Jakub Szymkowiak
}

Received: 27 February 2013/Revised: 18 July 2013 / Accepted: 22 July 2013/Published online: 2 August 2013

(c) Springer International Publishing AG 2013

\begin{abstract}
Habitat selection is a decision-making process that birds use to select a habitat in which they live. It is crucial for individuals to make the correct choices, because their living space directly affects their fitness. When making settlement decisions, birds are faced with uncertainty about habitat quality. In order to reduce it, they have to acquire information, which makes their world more predictable. Acquisition and use of information about habitat quality is the central part of the habitat selection process. Individuals can acquire information about habitat quality in various ways, e.g., by using own breeding experience (personal information), or by observing behavior and decisions made by other individuals (social information). In this review I briefly described the types of social information which songbirds use to assess the habitat quality. By using unified approach, I evaluated their value and availability for individuals, concluding that simultaneous use of several types of information provide the most effective way to habitat quality assessment. Furthermore, I argued why tits (Paridae) constitute a crucial link in the chain of interspecific social information transfer within songbirds' communication networks throughout the Holarctic and suggested that they may be considered as the keystone cue-providers. Moreover, I evaluated current literature on the artificial-attraction methods and highlighted urgent research needs in context of its practical application in the conservation and management of songbirds populations.
\end{abstract}

J. Szymkowiak ( $₫)$

Department of Avian Biology and Ecology, Faculty of Biology,

Adam Mickiewicz University, Collegium Biologicum,

Umultowska 89, 61-614 Poznan, Poland

e-mail: jszym@amu.edu.pl
Keywords Songbirds - Habitat selection - Personal information $\cdot$ Social information

\section{Introduction}

When making various decisions, such as where to settle, with whom to breed, and where to forage, individuals are faced with uncertainty every day during the breeding period. In order to reduce this uncertainty they have to acquire information which makes their world more predictable [29, 128, 131]. The more information about an environment they acquire, the better they can adjust their behavior when making decisions [25]. Otherwise, making bad decisions can lead to dramatic results, such as breeding failure or reduced survival [32]. That is why effective acquisition and appropriate use of information is crucial for the adaptation processes [25, 118, 128, 156] and underlies life [60]. Mechanisms of acquiring, using, and sharing information among individuals, thus constitute one of the central concept in modern biology [75, 88, 128, 156].

Block and Brennan [11] defined habitat selection as: "Innate and learned behavioral responses of birds that allow them to distinguish among various components of the environment resulting in the disproportional use of environmental conditions (...)." Undoubtedly, habitat choice affects survival, opportunities to attract a partner, and successful breeding, thus is directly linked with individuals' fitness [11, 22, 27, 85, 100]. Moreover, choices made by each individual have wider implications for the population regulation and viability $[11,32]$. In metapopulation, if individuals aggregate in some patches and leave other unoccupied, then the overall probability of metapopulation extinction may increase due to the increased risk of simultaneous extinction of all subpopulations [32]. 
Furthermore, using social information may be considered as proximate cause in the evolution of sociality and group living, e.g., coloniality [27, 32]. It is important to understand habitat selection not as an observed pattern of species/individuals distribution, but rather as a hierarchical decision-making process that leads to it. The acquisition and use of information about habitat quality constitute the central part of this complex process $[33,71,78,103,120]$.

Songbirds can acquire social information by observing behavior and decisions made by other individuals $[25,29$, 32]. In the habitat selection process, this information can be based on the presence of other individuals in a given habitat (location cues) $[25,29]$ or their breeding success (public information) [25, 29, 152]. Location cues and public information can be obtained both from con- and heterospecifics (e.g., [93, 113, 138, 152]). There are some interesting parallels between using social information and signaling. In fact, socially acquired information is nothing other than the eavesdropped personal information of other individuals. According to Seppänen et al. [130] and Schmidt et al. [128] this follows a sequence: (i) observation (of information producer by primer observer), (ii) a decision (a change in observer behavior as a result of obtaining information), and (iii) the consequence (an effect of observer' behavior change). Eavesdropping is a welldescribed phenomenon in animal communication studies, however, often considered mainly in context of alarm calls or song contests between males (e.g., [83, 90, 117, 143]). The phenomenon of using social information in habitat selection process suggests that within communication networks songbirds can share also information about habitat quality. Knowledge about how birds make decisions about where to settle is crucial to understand the general mechanisms of habitat selection process.

The knowledge about how individuals choose their breeding sites is not purely academic, but has a strong influence on how the birds' population should be conserved and managed $[1,3,158]$. The scientists' world needs to understand how birds use their environment in time and space to effectively protect them. By utilizing artificial manipulation of social cues, based on which birds assess habitat quality, researchers are able to attract them into theoretically optimal, but previously unoccupied sites (e.g., [2]). Therefore, manipulation of social information is considered as a potential highly effective tool in conservation and management ([3] for review). An interesting field of study is to address the implications arising from the use of social information by species in habitat modeling [17]. Beside purely scientific reasons, species distribution models are commonly used in animal ecology and provide useful tool for wildlife management. By incorporating parameters that result from the use of social information (e.g., clustered distribution) scientists can improve models' predictive ability [17]. Thus, understanding habitat selection may allow us to designate areas for protection more precisely, or predict impact of habitat modification e.g., urbanization on species distribution.

The aim of this review is to summarize knowledge regarding the acquisition and use of social information about habitat quality in the habitat selection process. The article is focused on small songbirds (Passeri), nonetheless many addressed issues can be considered in wider context of social information acquiring and use among other taxa as well. In the first part of this review I describe sources of social information, which songbirds may use to assess habitat quality in the habitat selection process. The second part presents how individuals choose between different types of information and what are the costs and benefits of using social cues and being such cue for other individuals. I also consider some practical aspects of using artificialattraction methods in the conservation of songbirds.

\section{Social Information Use in Habitat Selection Process}

When making settlement decisions, birds can acquire information about habitat quality based on direct interactions with the environment, by using trial-and-error strategy $[25,29,32,33]$. However, in order to make a reliable assessment of the habitat quality, individuals should take into account multiple cues, e.g., vegetation structure, food resources, the presence of parasites, or predation pressure $[15,16,22,25,71,93]$. Direct sampling so much information from several habitat patches can be time- and energy-consuming [3, 21, 33, 93, 97]. Moreover, some of this information may not be available to individuals at the time of the decision-making process, hence it can be impossible to collect them [32, 82, 130]. Using own breeding experience as a form of information and make settlement decisions according to the rule: return to the site where species successfully breed, change it if failed (the so-called "win stay:lose switch rule") seems to be more profitable. In fact, many species demonstrate high breeding-site fidelity, if they achieved high reproductive success in a particular place in the previous season $[12,37,57,62$, $65,111,119]$. However, information about breeding experience grows as a function of time and is directly related to the age of individuals and number of broods during their life. Moreover, "win stay:lose switch rule" leads to a further question - if a given individual decides to "switch," then how do they acquire information about habitat quality to make subsequent settlement decisions?

Instead of personal information (e.g., own experiences or trial-and-error strategy), birds can acquire several types of social information by monitoring behavior and decisions made by other individuals [25, 29, 32]. An important 
impulse to start research on the use of social information by birds was a paper published by Ward and Zahavi [160] in which they developed "information-center hypothesis." According to this hypothesis, individuals form clusters in order to obtain information about the location of food from other individuals [160]. Nowadays, many studies show that social information is used by birds not only in foraging behavior [25, 98], but also in many other contexts, e.g., when choosing breeding habitats [25, 29, 98] and nest location [82], or selecting a partner for reproduction [25, 98]. When making settlement decisions, social information can be acquired in two ways. First, birds can use location cues - the presence of other individuals in a given habitat $[25,29]$. Location cues can be acquired both from con- and heterospecifics and are called then conspecific and heterospecific cues, respectively [29, 94, 96, 97, 138, 139]. The second type of social information that can be used by birds in habitat selection process is public information (the socalled habitat copying hypothesis) $[13,27,33,151,152]$. In this case, birds use the breeding performance of other individuals as a cue when making settlement decisions [29, 152]. Public information, as well as location cues, can be obtained both from con- and heterospecifics [29, 110, 152]. Below I briefly characterized different types of social information which are used by songbirds when making settlement decisions.

\section{Conspecific Cues}

Breeding density in a particular habitat is usually a function determined by its quality [22, 55, 56, 76]. Conspecifics overlap their ecological niches, thus depending on the same resources and the same environmental factors (e.g., predators and parasites) affect their fitness. Hence, birds can use the presence of conspecifics as a cue when making settlement decisions [2, 3, 4, 27, 29, 66, 67, 138, 139, 158]. If birds use conspecific cues, they prefer to settle in habitat patches already occupied, near other individuals. This breeding-site selection strategy was coined by Stamps [137-139] and defined as conspecific attraction. Stamps [137-139] studied habitat selection in Bronze Anole (Anolis aeneus) lizards; however, today the vast majority of research on the conspecific attraction refers to birds (e.g., [8, 69, 92, 105, 106, 148, 158], Table 1). The most extreme examples of settling near conspecifics are colonially breeding seabirds. In songbirds, more intuitive will be conspecific avoidance rather than attraction, because individuals usually actively defend their living space. However, conspecific attraction was described also in territorial songbirds (e.g., [3, 84 , 106, 115, 145, 148, 158]). Conspecific cues are used by songbirds not just in breeding habitat selection process. The Yellow-breasted Chat (Icteria virens) use nocturnal song of conspecifics for choice of stopover habitats during migration [5]. Moreover, acquiring and using conspecific cues in habitat selection is most commonly reported for migratory species. However, also residents, e.g., the Cape Sable Seaside Sparrow (Ammodramus maritimus mirabilis) [154] or Blue Tit (Cyanistes caeruleus) [112] can use the information about the conspecifics' presence when making settlement decisions.

\section{Heterospecific Cues}

Birds can use multiple heterospecifics cues as a source of information in habitat selection (e.g., [51, 93, 94, 97, 146]). The presence of predators in a given habitat negatively affects settlement likelihood by potential preys [45, 54, 87, 99, 147]. Though the competitors' presence may also negatively affect breeding-sites selection due to heterospecific avoidance [64, 86, 93], however, there is also another possible scenario. If ecological niches of two species overlap significantly, then the presence of one of them in the habitat patch may be the settlement cue for the second [48, 93, 94, 96, 97, 148]. The more their niches overlap, the more they rely on equal resources and similar ecological factors affect their fitness. Paradoxically, the most valuable cue reflecting habitat quality may be, therefore, the presence of the strongest competitors [51, 93, $94,110,130]$. When using heterospecific cues, birds prefer to settle near species with similar ecological niches. This strategy of selecting breeding sites was coined by Mönkkönen et al. [94] and named heterospecific attraction. Among songbirds, heterospecific attraction has been reported so far only on the examples when migratory species e.g., the Chaffinch (Fringilla coelebs) and the Willow Warbler (Phylloscopus trochilus) use residents, e.g., the Willow Tit (Parus montanus) and the Great Tit (Parus major) as a source of information [51, 93, 94, 146], Table 2). That can be explained due to the fact that migrants have strongly limited opportunities to invest large amounts of time and energy for searching habitats to acquire information about their quality [50, 93, 94, 97]. Residents, on the other hand, remain in breeding areas throughout the year, even if they rarely maintain strict territories outside the breeding season; therefore, they have a lot of time for an accurate assessment of habitat quality [50, 93, 94, 97]. The presence of residents may reflect habitat quality directly (choice that they made) or indirectly, by their different winter survivals (a larger fraction survive in habitats of better quality) [50]. Perhaps the easiest way to acquire information about the density of residents in a given habitat patch is by simple monitoring their physical presence. However, Hromada et al. [72] showed that the Red-backed Shrike (Lanius collurio) use larders of the Great-gray Shrike (Lanius excubitor) as heterospecific cues and that they were attracted to plots 
Table 1 Species experimentally tested for a conspecific attraction with artificial manipulation of location cues

\begin{tabular}{|c|c|c|c|c|c|c|c|c|}
\hline \multirow[t]{2}{*}{ Species } & \multirow[t]{2}{*}{ Location } & \multirow[t]{2}{*}{$\begin{array}{l}\text { Cue } \\
\text { type }\end{array}$} & \multirow[t]{2}{*}{$\begin{array}{l}\text { Cue } \\
\text { timing }\end{array}$} & \multicolumn{2}{|c|}{$\begin{array}{l}\text { Short-term } \\
\text { effect }^{\mathrm{a}}\end{array}$} & \multicolumn{2}{|c|}{$\begin{array}{l}\text { Long-term } \\
\text { effect }^{\mathrm{b}}\end{array}$} & \multirow[t]{2}{*}{ Citation } \\
\hline & & & & Pop $^{c}$ & $\mathrm{BS}^{\mathrm{d}}$ & Pop $^{c}$ & $\mathrm{BS}^{\mathrm{d}}$ & \\
\hline Baird's Sparrow (Ammodramus bairdii) & North Dakota (USA) & $\mathrm{P}$ & Pre & $\mathrm{CO}$ & $?$ & $?$ & $?$ & Ahlering et al. [2] \\
\hline \multirow[t]{2}{*}{ Saltmarsh Sparrow (Ammodramus caudacutus) } & Connecticut (USA) & $\mathrm{P}$ & Pre, Bre & NR & - & - & - & $\begin{array}{l}\text { Bayard and Elphick } \\
\text { [7] }\end{array}$ \\
\hline & Connecticut (USA) & $\mathrm{P}$ & $\begin{array}{l}\text { Bre, } \\
\text { Post }\end{array}$ & NR & - & - & - & $\begin{array}{l}\text { Bayard and Elphick } \\
\text { [7] }\end{array}$ \\
\hline Seaside Sparrow (Ammodramus maritimus) & Florida (USA) & $\mathrm{P}$ & Pre & ID & $?$ & $?$ & $?$ & Virzi et al. [154] \\
\hline \multirow[t]{2}{*}{ Nelson's Sparrow (Ammodramus nelsoni) } & $\begin{array}{l}\text { Nova Scotia } \\
\text { (Canada) }\end{array}$ & $\mathrm{P}, \mathrm{D}$ & Pre & NR & - & - & - & Nocera et al. [105] \\
\hline & $\begin{array}{l}\text { Nova Scotia } \\
\text { (Canada) }\end{array}$ & $\mathrm{P}, \mathrm{D}$ & Post & NR & - & - & - & Nocera et al. [105] \\
\hline \multirow[t]{2}{*}{$\begin{array}{l}\text { Black-throated Blue Warbler (Dendroica } \\
\text { caerulescens) }\end{array}$} & Michigan (USA) & $\mathrm{P}$ & Pre & ID & $?$ & $?$ & $?$ & $\begin{array}{l}\text { Hahn and Silverman } \\
\text { [67] }\end{array}$ \\
\hline & $\begin{array}{l}\text { New Hampshire } \\
\text { (USA) }\end{array}$ & $\mathrm{P}, \mathrm{D}$ & Post & $\mathrm{CO}$ & $?$ & $?$ & $?$ & Betts et al. [8] \\
\hline \multirow{2}{*}{$\begin{array}{l}\text { Golden-cheeked Warbler (Dendroica } \\
\text { chrysoparia) }\end{array}$} & Texas (USA) & $\mathrm{P}$ & Pre & ID & ND & $?$ & $?$ & Farrell et al. [38] \\
\hline & Texas (USA) & $\mathrm{P}$ & Post & ID & ND & $?$ & $?$ & Farrell et al. [38] \\
\hline \multirow[t]{2}{*}{ Bobolink (Dolichonyx oryzivorus) } & $\begin{array}{l}\text { Nova Scotia } \\
\text { (Canada) }\end{array}$ & $\mathrm{P}, \mathrm{D}$ & Pre & NR & - & - & - & Nocera et al. [105] \\
\hline & $\begin{array}{l}\text { Nova Scotia } \\
\text { (Canada) }\end{array}$ & $\mathrm{P}, \mathrm{D}$ & Post & $\mathrm{CO}$ & $?$ & $?$ & $?$ & Nocera et al. [105] \\
\hline \multirow[t]{3}{*}{ Least Flycatcher (Empidonax minimus) } & Ontario (Canada) & $\mathrm{P}, \mathrm{D}$ & Pre & NR & - & - & - & Mills et al. [92] \\
\hline & Montana (USA) & $\mathrm{P}$ & Pre & ID & $?$ & $?$ & $?$ & Fletcher [40] \\
\hline & Montana (USA) & $\mathrm{P}$ & Pre & $\mathrm{CO}$ & $?$ & $?$ & $?$ & Fletcher [42] \\
\hline Pied Flycatcher (Ficedula hypoleuca) & Sweden & $\mathrm{P}$ & Pre & $\mathrm{CO}$ & $?$ & $?$ & $?$ & Alatalo et al. [4] \\
\hline \multirow[t]{2}{*}{ American Redstart (Setophaga ruticilla) } & Michigan (USA) & $\mathrm{P}$ & Pre & ID & $?$ & $?$ & $?$ & $\begin{array}{l}\text { Hahn and Silverman } \\
\text { [66] }\end{array}$ \\
\hline & Montana (USA) & $\mathrm{P}$ & Pre & ID & $?$ & $?$ & $?$ & Fletcher [40] \\
\hline Brewer's Sparrow (Spizella breweri) & $\begin{array}{l}\text { British Columbia } \\
\text { (Canada) }\end{array}$ & $\mathrm{P}$ & Pre & $\mathrm{CO}$ & ND & - & - & Harrison et al. [69] \\
\hline Black-capped Vireo (Vireo atricapilla) & Texas (USA) & $\mathrm{P}, \mathrm{D}$ & Pre & $\mathrm{CO}$ & IS & $\mathrm{R}$ & $\mathrm{S}$ & $\begin{array}{l}\text { Ward and Schlossbers } \\
\text { [158] }\end{array}$ \\
\hline $\begin{array}{l}\text { Yellow-headed Blackbird (Xanthocephalus } \\
\text { xanthocephalus) }\end{array}$ & Illinois (USA) & $\mathrm{P}, \mathrm{D}$ & Pre & NR & - & - & - & Ward et al. [161] \\
\hline
\end{tabular}

$P$ playback, $D$ decoys, Pre cue provided during pre-breeding period, Bre cue provided during breeding period, Post cue provided during postbreeding period

${ }^{a}$ Effect in year of experimental manipulation

${ }^{\mathrm{b}}$ Effect in year(s) after experimental manipulation

${ }^{\mathrm{c}}$ Population: $\mathrm{CO}$ - (colonized) attraction to a previously unoccupied sites, ID—(increased density) increase of density on sites with experimental manipulation, NR-(no response) no effect of manipulation, R—birds return in following year after experimental manipulation?-no relevant data given

${ }^{\mathrm{d}}$ Breeding success: ND—no difference in breeding success (number of fledglings) between treatment and control sites, IS—increased breeding success (number of fledglings) on treatment sites, S-successful breeding after returning to previously manipulated sites, ?-no relevant data given

with experimentally added larders, even without the physical presence of the Great-gray Shrike individuals on these plots. These results show that at least some songbirds have ability to acquire heterospecific cues also in more complex and sophisticated ways.
Public Information

Another type of social information, that can be used to assess habitat quality, is public information [25, 29, 33, 98, 151, 152]. This term was defined by Valone [150] in 
Table 2 Species experimentally tested for a heterospecific attraction with artificial manipulation of location cues

\begin{tabular}{|c|c|c|c|c|c|c|}
\hline \multirow[t]{2}{*}{ Cue-provider } & \multirow[t]{2}{*}{ Cue-user(s) } & \multirow[t]{2}{*}{ Location } & \multirow{2}{*}{$\begin{array}{l}\text { Manipulation } \\
\text { type }\end{array}$} & \multicolumn{2}{|c|}{ Short-term effect ${ }^{\mathrm{a}}$} & \multirow[t]{2}{*}{ Citation } \\
\hline & & & & Population $^{\mathrm{b}}$ & $\begin{array}{l}\text { Breeding } \\
\text { success }^{\mathrm{c}}\end{array}$ & \\
\hline \multirow[t]{4}{*}{$\begin{array}{l}\text { Great Tit (Parus major) Blue Tit (Cyanistes } \\
\text { caeruleus) }\end{array}$} & Foliage gleaners $^{\mathrm{d}}$ & $\begin{array}{l}\text { Gotland } \\
\text { (Sweden) }\end{array}$ & $\mathrm{NB}, \mathrm{R}, \mathrm{T}$ & $\mathrm{P}$ & $?$ & $\begin{array}{l}\text { Forsman } \\
\text { et al. [52] }\end{array}$ \\
\hline & Ground foragers $^{\mathrm{e}}$ & $\begin{array}{l}\text { Gotland } \\
\text { (Sweden) }\end{array}$ & $\mathrm{NB}, \mathrm{R}, \mathrm{T}$ & NR & $?$ & $\begin{array}{l}\text { Forsman } \\
\text { et al. [52] }\end{array}$ \\
\hline & Migrant birds ${ }^{\mathrm{d}, \mathrm{e}}$ & $\begin{array}{l}\text { Gotland } \\
\text { (Sweden) }\end{array}$ & $\mathrm{NB}, \mathrm{R}, \mathrm{T}$ & $\mathrm{P}$ & $?$ & $\begin{array}{l}\text { Forsman } \\
\text { et al. [52] }\end{array}$ \\
\hline & $\begin{array}{l}\text { Collared Flycatcher } \\
\quad \text { (Ficedula albicollis) }\end{array}$ & $\begin{array}{l}\text { Gotland } \\
\text { (Sweden) }\end{array}$ & $\mathrm{NB}, \mathrm{R}, \mathrm{T}$ & $\mathrm{U}$ & $\mathrm{U}$ & $\begin{array}{l}\text { Forsman } \\
\text { et al. [51] }\end{array}$ \\
\hline Great-Gray Shrike (Lanius excubitor) & $\begin{array}{l}\text { Red-backed Shrike } \\
\text { (Lanius collurio) }\end{array}$ & $\begin{array}{r}\text { Odolanów } \\
\text { (Poland) }\end{array}$ & $\mathrm{L}$ & $\mathrm{P}$ & $?$ & $\begin{array}{l}\text { Hromada } \\
\text { et al. [72] }\end{array}$ \\
\hline \multirow[t]{5}{*}{$\begin{array}{l}\text { Great Tit, Blue Tit, Willow Tit (Parus } \\
\text { montanus) }\end{array}$} & Foliage gleaners ${ }^{\mathrm{f}}$ & $\begin{array}{l}\text { Oulu } \\
\text { (Finland) }\end{array}$ & $\mathrm{NB}, \mathrm{F}$ & $\mathrm{P}$ & $?$ & $\begin{array}{l}\text { Thomson } \\
\text { et al. [146] }\end{array}$ \\
\hline & Ground foragers ${ }^{\mathrm{g}}$ & $\begin{array}{l}\text { Oulu } \\
\text { (Finland) }\end{array}$ & $\mathrm{NB}, \mathrm{F}$ & NR & $?$ & $\begin{array}{l}\text { Thomson } \\
\text { et al. [146] }\end{array}$ \\
\hline & Habitat specialists ${ }^{\mathrm{h}}$ & $\begin{array}{l}\text { Oulu } \\
\text { (Finland) }\end{array}$ & $\mathrm{NB}, \mathrm{F}$ & NR & $?$ & $\begin{array}{l}\text { Thomson } \\
\text { et al. [146] }\end{array}$ \\
\hline & Habitat generalists ${ }^{\mathrm{i}}$ & $\begin{array}{l}\text { Oulu } \\
\text { (Finland) }\end{array}$ & $\mathrm{NB}, \mathrm{F}$ & $\mathrm{P}$ & $?$ & $\begin{array}{l}\text { Thomson } \\
\text { et al. [146] }\end{array}$ \\
\hline & $\begin{array}{l}\text { Pied Flycatcher } \\
\text { (Ficedula hypoleuca) }\end{array}$ & $\begin{array}{l}\text { Northern } \\
\text { Finland }\end{array}$ & $\mathrm{NB}, \mathrm{R}$ & $?$ & $\mathrm{P}$ & $\begin{array}{l}\text { Forsman } \\
\text { et al. [49] }\end{array}$ \\
\hline $\begin{array}{l}\text { Willow Tit, Great Tit, Siberian Tit (Parus } \\
\text { cinctus) }\end{array}$ & Migrant species ${ }^{\mathrm{j}}$ & $\begin{array}{l}\text { Meltaus } \\
\text { (Finland) }\end{array}$ & $\mathrm{F}, \mathrm{R}$ & $\mathrm{P}$ & $?$ & $\begin{array}{l}\text { Forsman } \\
\text { et al. [48] }\end{array}$ \\
\hline $\begin{array}{l}\text { Black-capped Chickadee (Parus } \\
\text { atricapillus), Red-breasted Nuthatch (Sitta } \\
\text { canadensis), White-breasted Nuthatch } \\
\text { (Sitta carolinensis) }\end{array}$ & Migrant species ${ }^{\mathrm{k}}$ & $\begin{array}{l}\text { Minnesota } \\
\text { (USA) }\end{array}$ & $\mathrm{F}, \mathrm{R}$ & $\mathrm{P}$ & $?$ & $\begin{array}{c}\text { Mönkkönen } \\
\text { et al. [96] }\end{array}$ \\
\hline Willow Tit, Great Tit & $\begin{array}{l}\text { Willow Warbler } \\
\text { (Phylloscopus } \\
\text { trochilus), Chaffinch } \\
\text { (Fringilla coelebs) }\end{array}$ & $\begin{array}{r}\text { Konnevesi } \\
\text { (Finland) }\end{array}$ & $\mathrm{NB}, \mathrm{F}, \mathrm{R}, \mathrm{T}$ & $\mathrm{P}$ & $?$ & $\begin{array}{l}\text { Mönkkönen } \\
\text { et al. [94] }\end{array}$ \\
\hline
\end{tabular}

$N B$ increased density of cue-providers via availability of nest boxes, $F$ increased density of cue-providers via winter feeding, $R$ decreased density of cue-providers by removal, $T$ cue-providers density manipulated by catching with mist-nets and transferring, $L$ manipulated the presence of larders of great-gray shrikes

${ }^{a}$ Response of cue-users in year of experimental manipulation

${ }^{\mathrm{b}}$ Relationship between cue-providers density and density of cue-users: $P$ positive, $U$ unimodal, $N R$ no relationship, ?: no relevant data given

c Relationship between cue-users breeding success and density of cue-providers: $P$ positive, $U$ unimodal, ?: no relevant data given

${ }^{\mathrm{d}}$ Chaffinch, Willow Warbler, Blackcap (Sylvia atricapilla), Garden Warbler (S. borin), Whitethroat (S. communis), Lesser Whitethroat (S. curruca), Wood Warbler (Phylloscopus sibilatrix), and Icterine Warbler (Hippolais icterina)

${ }^{\mathrm{e}}$ Robin (Erithacus rubecula), Song Thrush (Turdus philomelos), Redwing (T. iliacus), Wren (Troglodytes troglodytes), and Wood Pipit (Anthus trivialis)

${ }^{\mathrm{f}}$ Chaffinch, Willow Warbler, Garden Warbler

g Robin, Redwing, Tree Pipit

${ }^{\mathrm{h}}$ Redwing, Spotted Flycatcher (Muscicapa striata), Garden Warbler

${ }^{i}$ Chaffinch, Willow Warbler, Robin, Tree Pipit

${ }^{\mathrm{j}}$ Brambling (Fringilla montifringilla), Willow Warbler, Spotted Flycatcher, Wood Pipit, Redwing, Chaffinch, Eurasian Siskin (Carduelis spinus), Mistle Thrush (Turdus viscivorus), Pied Flycatcher, Common Redstart (Phoenicurus phoenicurus)

${ }^{\mathrm{k}}$ Red-eyed Vireo (Vireo olivaceus), American Redstart (Setophaga ruticilla), Chestnut-sided Warbler (Dendroica pennsylvanica), Ovenbird (Seiurus aurocapillus), Least Flycatcher (Empidonax minimus), Yellow-rumped Warbler (Dendroica coronata) Northern Flicker (Colaptes auratus), Veery (Catharus fuscescens), American Robin (Turdus migratorius), Yellow Warbler (Dendroica petechia), Black-and-white Warbler (Mniotilta varia), Magnolia Warbler (Setophaga magnolia), Song Sparrow (Melospiza melodia) 
context of foraging behavior as: "information about the quality of a patch that can be obtained by observing the foraging success of the other individuals in that patch." In habitat selection process, birds can acquire public information by monitoring breeding success of other individuals [13, 26, 27, 29, 33, 98, 151, 152]. Therefore, public information integrates the overall effect of many ecological factors on local reproductive success, thus is more strictly related to the quality than the location itself, which distinguishes it from other types of social information [28, 29, $33,114,151]$. In case individuals use public information to assess habitat quality, they demonstrate strong fidelity to sites where the neighbors' reproductive success is high $[29,98,151,152]$, which is the so-called "habitat copying hypothesis" [28, 110, 155]) Such dispersal pattern was observed e.g., in the Collared Flycatcher (Ficedula albicollis) on Gotland [33, 35, 36, 114] and the Yellow-headed Blackbirds (Xantocephalus xantocephalus) [157]. Public information can be obtained by monitoring performance of individuals from the same species as well as by assessing breeding success of individuals from other species with similar niche (e.g., [33, 110]). Nevertheless, using public information obtained from heterospecifics has not been described for the example of songbirds yet.

\section{Tits_-The Keystone Information Providers}

The concept of keystone species was proposed by Paine [108, 109] to describe species whose presence in ecosystems is essential to maintain the organization and diversity of entire communities. Woodpeckers, for example, are considered as keystone species in forest ecosystems, because they provide cavities for many secondary cavitynesters, interact with wood-rotting fungi as its dispersalvectors, etc. [153]. So far, the keystone species hypothesis was proposed in the context of e.g., keystone predators, preys, or hosts [91]. There are many documented examples of interspecific social information transfer between tits (Paridae) and other bird species, e.g., in the habitat selection process, risk assessing, or foraging behavior. Below I argue why tits may be considered as the keystone information providers.

Tits are widespread songbirds in the Holarctic and occur in many habitats, but mainly inhabit forests and woodlands [68]. As residents, they have a lot of time to thoroughly evaluate the quality of habitat [93, 94, 97], and their presence in a particular habitat patch reflects its quality directly (choice made by them) or indirectly (different winter survivals) [50]. Thus, they are potentially a valuable source of information about habitat quality for many forest songbirds. Indeed, in studies on heterospecific attraction, in 6 of 7 cases, the cue-providers were resident tits, e.g., Great
Tit, Blue Tit, and Willow Tit (Table 2). Among species which use tits as habitat quality indicators are e.g., the Garden Warbler (Sylvia borin), Icterine Warbler (Hippolais icterina), or Lesser Whitethroat (Sylvia curruca) (Table 2). Songbirds may use tits as cues in habitat selection process to make decisions at various spatial scales, e.g., in landscape scale, to select habitat patch, or in smaller scale, when choosing the nest location [49]. By making decisions on nest location, songbirds sometimes can even blindly copy tits' decisions [129]. Hence, using tits as cues in habitat selection process may affect spatial distribution of cue-users populations. Experimental studies made in Scandinavia and North America showed that enhanced densities of breeding tits caused numerical response in entire breeding bird communities, e.g., foliage gleaners, migrants, or habitat generalists (Table 2). Thus, heterospecific attraction in which tits provide information about habitat quality for other species may be considered as one of the main factors that affect songbirds community structure and abundances in forest ecosystems [96].

Tits as well as many other songbirds produce alarm signals when they detect a potential predator. However, tits' alarm calls constitute perhaps one of the most sophisticated signaling systems about danger yet discovered among songbirds. Templeton et al. [144] showed that acoustic features of the alarm calls produced by Blackcapped Chickadees (Poecile atricapillus) vary with the size of the predator. Then, in playback experiments he demonstrated that chickadees are able to detect this information and adjust mobbing behavior in relation to the degree of threat that a particular predator represent. Such allometry of alarm calls which encode information about threat was also reported on the examples of other tit species, the Carolina Chickadees (Poecile carolinensis) and Tufted Titmouses (Baeolophus bicolor) [24, 133, 136]. In forest communication networks, there are many potential heterospecific eavesdroppers of such signals, especially birds with similar body size to tits, because they are often prey of similar predators [143]. In fact, Templeton and Greene [143] showed that Red-breasted Nuthatches (Sitta canadensis) respond differently to subtle variations of Blackcapped Chickadees alarm calls, thereby are able to correctly interpret information encoded in these signals. Also other studies showed that songbirds may use tits as a source of information about predation risk [46, 73, 104], thus it is potentially a widespread phenomenon.

Tits are well-known participants of mixed-species foraging aggregations [68]. As in case of habitat selection process and alarm communication networks, in foraging behavior also tits are information providers for other songbirds. Mönkkönen et al. [95] tested whether different songbird species are associated with each other during foraging. He observed that, in comparison with control 
treatments, more species spent their time foraging when he played back the song of the Willow Tit and suggested that songbirds may use tits to locate the high-quality foraging sites. In deciduous forest of North America, mixed-species foraging flocks are composed of two tit species-Tufted Titmouse and either Carolina Chickadee or Black-capped Chickadee and also several satellite species, e.g., Whitebreasted Nuthatches (Sitta carolinensis) [30, 31]. Tits act as flock leaders, while other species closely follow them and take benefits from this strategy, e.g., decrease their vigilance and spent more time foraging. Moreover, tits may even facilitate forest-boundary crossing by heterospecific flock mates, this increases their access to new habitats and expands their foraging niches breadth [132].

Many songbirds use tits as a source of social information to make various decisions that are crucial in their live. Based on their presence or behavior, songbirds make decisions on foraging or breeding-sites selection at multiple spatial scales. In alarm communication networks, tits constitute a central link by providing complex alarm signals for other community members. Moreover, in an elegant experiment, Forsman et al. [53] showed that Pied Flycatchers (Ficedula hypoleuca) use information about tits' clutch size to adjust their own investment in offspring. All of these features make tits a crucial link in the chain of interspecific social information transfer, which affects the structure and functioning of breeding birds communities throughout the Holarctic. Therefore, I suggest that they can be considered as the keystone information providers.

\section{When to Use Different Types of Social Information?}

When environment varies in time and space, but at least partially in a predictable way, birds may improve settlement decisions by acquiring information about habitat quality [25, 34, 130]. In order to be useful for individuals when they choose breeding sites, information must allow them to evaluate the quality of habitats and thus predict the expected fitness and compare alternative habitat patches [32]. From the individuals perspective two features can describe the information: availability and value [36, 43, 128]. The first one can be defined as its accessibility to individuals [43] and depends on: (1) costs of acquiring, which may be either direct (e.g., exposure to predators), or indirect (loss of time spent on prospecting, which could be used for other activities) [120]; (2) the time at which the information is present in the environment (e.g., some cues may occur only in short time windows) [43, 128]; and (3) the perceptual range, that is the capacity to perceive specific cues resulting from the cognitive and sensory abilities of individuals [43]. According to Fletcher and Sieving [43] and Morand-Ferron et al. [98] definitions, the value of information can be described as the difference in fitness between individuals that make decisions based on acquired information over naive one. Therefore, information value can be defined as its ability to reduce uncertainty and improving decisions. Doligez and Boulinier [32] mentioned that it depends on several factors, e.g.: (1) temporal predictability of habitat quality between acquiring and use of information and the result of a decision taken based on it; (2) its reliability, therefore, the risk of being deceived by information producer; (3) degree to which the cue variability reflects environmental variation (covariation between the cue and environment); and (4) degree to which the cue is related to fitness. In breeding-sites selection strategies, birds use various types of information (e.g., personal information, public information, etc.), that are characterized by a different value and availability. Therefore, according to the definition proposed by Fletcher and Sieving [43], "the likelihood of information being used is a function of its perceived value, conditional on the availability of information to an individual."

\section{Location Cues-A Trade-off Between Value and Availability}

Information about location of other individuals (both, conand heterospecifics) can be acquired easily and at low cost [3, 36, 138], because they are available both prior to breeding (thus, prior to obtaining personal information) and in post-breeding time [3, 130]. Therefore, this type of information can be used in the year of its acquirement, as well as to select the future breeding sites. Songbirds can assess location of other individuals using vocal (singing behavior) or visual (direct observation of other individuals) cues. The ability to locate other individuals will depend on the perceptual range i.e., the distance from which individual can recognize specific cues. It is a well-studied subject in bioacoustics and now there is no doubt that birds use e.g., song degradation as a cue when assessing distance between individuals (ranging hypothesis) [89, 101, 102]. Typically, location cues are characterized by the relatively high availability and their value will depend primarily on their relationship with individuals' fitness. Usually, habitat quality is better reflected by the reproductive success of individuals which breed in it than their density ([22, 36, 76]; Fuller 20). The performance-based types of information (personal and public information) can better predict fitness of individuals, and thus have a greater value. However, information about the occurrence of individuals in a particular habitat also reflects its quality to some extent, and may be obtained at a lower cost [34, 36, 76, 97]. The greater niches overlap between species, the more valuable cues they are to each other. Thus, it might seem that conspecifics are always better sources of information 
than individuals of other species, because they have perfect niche overlap. However, Seppänen et al. [130] suggested a more probable mechanism. According to his study, if the information from con- and heterospecifics is similar, then the knowledge acquired from heterospecifics is more valuable. This is because settling near heterospecifics, which occupy slightly different niches, leads to lower costs of competition [130]. Habitat selection, based on location cues, suggest positive density-dependence effect, although settling near other individuals (both con- and heterospecifics) in a particular habitat patch may be beneficial only to some threshold value of individuals' density. When this value is exceeded, competition costs are too high and individuals will benefit from avoiding settling in this habitat patch [34, 66]. Location cues value depends also on their reliability. It is assumed in the literature that social information is not intentionally produced so its worth should be more reliable [29]. This assumption seems to be true for public information, because individuals perform as well as possible, in the current environmental conditions. However, it may be incorrect in case of location cues, when birds use the singing activity of individuals to assess density of local population. Males of many songbirds have a repertoire of different song types which they use, instead of singing one version of their species song [20]. If males sing different songs in various places of their territories, then immigrants can overestimate the assessment of their density [80, 81]. For instance, an individual that sings 5 different songs may appear to another individual as 5 different birds. This phenomenon is known as the "Beau Geste hypothesis," proposed as one of the causes for the evolution of song repertoires. Krebs [80] suggested that: "(...) repertoires are used by resident birds to increase the apparent density of singing residents, and hence decrease the apparent suitability of the area to new birds." Then, Krebs et al. [81] performed a speaker replacement experiment to test this hypothesis. He removed males of the Great Tit from a small wood and divided study area into three subareas. On one of them, he played back a repertoire of Great Tit' song types, while the second subarea was defended by a single song type and the third was designed as a control silent area. The results provided evidence supporting the Beau Geste hypothesis, because immigrants almost immediately occupied the control area, then the single song-type area, while the subarea defended by a repertoire of song types was occupied last of all. These results have also wider implications for using social information in habitat selection process, because breeding density of tits is also a well-known location cue for many migrant songbirds [52, 94, 146]. Thus, there are some theoretical costs of being deceived when using location cues based on singing behavior of information producers. In such cases, overestimated assessment of population density is equivalent to the overestimated assessment of habitat quality, and may lead to settling in poorer habitats.

Public Information-High Value Limited by Low Availability

When individuals nest close to each other, e.g., in breeding colonies, information about the reproductive success of neighbors is readily available (e.g., [27]). However, noncolonial songbirds also use public information when making settlement decisions, including cavity-nesting birds (e.g., [33, 36, 114]). These individuals may assess the breeding success of others directly by nest inspection [47, 53] and indirectly, e.g., observing parental activity [35, 114]. Both strategies require thorough research, thus are time- and energy-consuming [36]. However, availability of public information may depend on the age of individuals, e.g., juveniles may have more limited access to public information than adults [36, 112], as well as can be inter-patch constrained [33]. The information about the location of individuals (location cues) is available throughout the breeding season, but their reproductive success can usually be assessed only in particular time windows [14, 128]. However, public information is based on performance of other individuals, and thus integrates the influence of all ecological factors on their fitness [34], therefore, it has a high value in assessing the quality of breeding habitats. Recent studies suggest that songbirds use public information with one-season delay, i.e., information obtained in year $T$ is used to make settlement decisions in year $T+1$ [33, 36, 157]. Nonetheless, this information may probably be used also in the year of its acquirement, e.g., in the second or even the first breeding attempt, if it was acquired from heterospecifics which start to breed sufficiently in advance.

Summarizing, performance-based types of information seem to have a greater value than the location cues, because reproductive success of individuals better reflects habitat quality than the density of the population [22, 36, $56,76]$. However, both personal and public information is more difficult to acquire than conspecific and heterospecific cues. The choice of a particular information type, which is used by individuals when making settlement decision, is a trade-off between its value and availability [36, 43, 59, 142]. Different models provide different results of this trade-off, depending on the initial input assumptions [13, 23, 39, 97, 126, 127, 130]. Using nonsocial vs. social information is often considered as a dichotomous process [122]. This assumption may be true for young individuals, which must often rely on location cues, because they have no own breeding experience and do not have access to public information (e.g., [36, 112]). Adult individuals, on the other hand, may combine different types of information and use it simultaneously. For example, they can use one of 
the performance-based types of information and update this information when making decisions in the next year using the readily available location cues. Indeed, research conducted by Parejo et al. [112] revealed that decisions about the dispersion of adult Blue Tits were dependent on their own breeding experience, public information, and location cues. In another study, adult Collared Flycatchers simultaneously used public information and conspecific cues, while yearlings made decisions based solely on conspecific cues [36]. Combining multiple types of information about habitat quality exhibits some parallels with using multimodal signals, i.e., signals that compose of two or more sensory modalities $[63,116,124]$. Although the function of multimodal signals in animal communication is not well understood, some authors suggested that each modality may serve to enhance the accuracy with which receivers assess a particular signal [19, 70, 77, 116]. Perhaps, by combining different types of information about habitat quality in habitat selection process, songbirds may be able to reduce uncertainty to a greater extent, which allows them to make more appropriate decisions about where to settle. However, the simultaneous use of several types of information in habitat quality assessment by songbirds is relatively unexplored field of research, thus we do not know much about this phenomenon.

\section{Evaluating the Outcome of Cue-Providers and Cue-Users Interactions}

Selecting breeding habitats based on social information is directly related with intra- and interspecific interactions. In these interactions two sides are involved: cue-users (individuals, which make decisions based on social cues) and cue-providers (individuals which are cues for other). Danchin et al. [29] mentioned that these interactions may be: (1) parasitism, when the cue-user gains benefits at the cue-provider' costs; (2) commensalism, when the cue-user benefits and succeeds the cue-provider the interaction is neutral; and (3) mutualism, when both sides succeed.

\section{Cost and Benefits for Cue-Users}

Social information can be obtained more quickly and at lower expense of energy than personal information [13, 34, 39, 59, 93, 97, 130, 138]. Hence, using it in the habitat selection process can improve the effectiveness of cueusers settlement decisions [29, 93, 98, 138]. Forsman et al. [49] showed that the Pied Flycatchers, which use the Great Tits as the heterospecific cues, settled and started breeding quicker on plots which densities of Great Tit were experimentally increased. Thus, social information allows to make settlement decisions more rapidly, than e.g., direct sampling of habitat quality by trial-and-error strategy [49]. Moreover, conspecific attraction leads to aggregated distribution of individuals' territories. By nesting in such aggregations, socially monogamous songbirds may increase their chances of obtaining extra-pair copulations, according to the "hidden-lek hypothesis", which is supported by studies conducted on the Least Flycatchers (Empidonax minimus) [140, 141]. Territories' aggregations may also provide protection against predators [3, 93, 138] in at least three different ways: (1) according to the "dilution effect hypothesis" [149], the more individuals in a limited space, the lower the risk of predation per capita; (2) a group of individuals can more rapidly detect the potential risk from predators than a single individual ("many eyes" or "group vigilance" hypothesis) [3, 123, 135, 138]; (3) individuals may use heterospecifics as a "protective umbrella," such as Bramblings (Fringilla montifringilla) and Redwings (Turdus iliacus), which are attracted to colonies of Fieldfare (Turdus pilaris) and benefit of communal defense against nest predators [134]. However, cue-users are faced also with some costs associated with the use of social information in habitat selection process, e.g., breeding clusters may facilitate localization of preys by predators [3, 74, 79]. Moreover, not all males may gain from nesting in the aggregations, and for some of them (e.g., subdominant males) it may be advantageous to avoid settling in groups with dominant males [3, 44, 61]. For cue-users, there is also a risk that blindly copying the decisions of other individuals will trigger an informational cascade [10, 59], which was originally described by economists in the context of decision-making process as blindly following choices made by others, without reference to the personal information [10]. In most cases, informational cascades refer to the correct decision, however can critically affect the initial stage of the habitat selection process [10, 59], if cue-users receive incorrect information at the time of choosing breeding sites, this may lead to their settling in poor habitats. In playback experiments, Rieucau and Giraldeau [122] reversed natural positive correlation between habitat quality and population density by providing location cues in suboptimal habitats. As a result of blindly trusting the social cues, inexperienced Nelson's Sparrows (Ammodramus nelsoni) and Bobolinks (Dolichonyx oryzivorus) were attracted to experimental plots and settled in poor habitats where they normally do not occur. Therefore, there exist some hypothetical costs for cue-users resulting from incorrect use of social information.

\section{Cost and Benefits for Cue-Providers}

The cost and benefits of being a cue for other individuals are poorly understood, because until now researchers have 
focused on it rather in the context of cue-users $[3,13,34$, $39,94,97,130,138]$. It seems that in conspecific attraction cue-users and cue-providers share them equally, except the benefits of the quicker and less costly assessment of habitat quality by cue-users. However, if we consider the situation of migrant species in which early-arriving individuals use e.g., heterospecific cues and simultaneously they provide location cues for conspecifics that arrive later, then they are both cue-users and cue-providers. In this scenario, such individuals also may gain benefits from quicker and less costly habitat quality assessment due to involving another side of interaction. Until today, heterospecific attraction was described for many migrants which use residents as a source of social information (e.g., [93, 96, 97, 148]). It is possible that early-arriving birds rely on heterospecific cues and simultaneously become cues for some individuals of their own species that arrive later and use conspecific cues to make settlement decisions. However, due to lack of appropriate data, this scenario remains theoretical and requires field studies. If birds use conspecific cues and cluster territories, then cue-users and cue-providers share the same cost and benefits associated with reproduction. Still it is very unlikely that heterospecific cue-providers increase the opportunity to find a female or to obtain extrapair copulations among individuals which use them [94]. Thus, aggregations formed as a result of heterospecific attraction probably do not provide benefits in terms of reproduction for any of the interaction' sides. As the most valuable cues seem to be individuals with very similar niches [51, 93, 94, 110, 130], cue-users and cue-providers often fall victim of the same predators. Therefore, in context of predation, cost and benefits resulting from the clustering distribution of individuals seem to be equal for cue-users and cue-providers regardless of the mechanism which leads to territories aggregation. However, when cueproviders are tracked by singing activity we should also consider the costs of vocalization which they pay. Some studies suggest that song production may not be a very energy-intensive process [107, 159]. However, singing males pay another cost of their activity, e.g., during singing they are exposed to heat loss, or when they sing while sitting on exposed perch, they are easy to locate by predators [159]. Furthermore, when conspecific males are clustered in close proximity to each other, there is a possibility that they will increase the overall amount or rate of singing, due to increased intrasexual competition. This may lead to reduction of the overall amount of time that they can spend on activities other than singing, e.g., foraging $[20,121]$.

Apart from theoretical considerations, lack of empirical data does not allow an accurate evaluation of the outcome of cue-providers and cue-users interactions. In fact, there is only one example that presents how being a cue-provider or cue-user affects fitness. Forsman et al. [50] in his study near Oulu (northern Finland) experimentally manipulated the location of nest boxes for Great Tits (cue-providers) and Pied Flycatchers (cue-users), in such way that they nested alone or close to each other. These tits which nested near flycatchers had fewer chicks and they were in poorer condition. Results of other studies, conducted in the same area showed that flycatchers gain benefits from using tits as settlement cues due to quicker selection of breeding habitats [49]. Flycatchers' benefits are also associated with their breeding success, because individuals which nested close to tits had larger clutches and heavier chicks [49]. Thus, it is a parasitic interaction, in which cue-user gain benefits (reduction in time spent searching for nesting sites and better performance), while cue-providers suffer as a result of fitness reduction. Sometimes in theoretical models, conspecific attraction is considered as an information parasitic strategy (e.g., [34]). It is very likely that these interactions are locally specific and that their outcome may vary from parasitism to mutualism depending on local environmental conditions. However, we still do not have adequate data from field studies to accurately assess this outcome.

If the nature of interactions between cue-users and cueproviders is to be understood, the scientists need to start investigating the economy of using social information in habitat selection process [122]. Especially, in case of empirical data about cost and benefits not only from the perspective of cue-user, but also from the perspective of individuals which are cues for other.

\section{Artificial-Attraction Methods for Conservation and Management}

\section{State of Knowledge}

It is often assumed that if the birds habitats are provided with an appropriate structure, they will find it and settle. This "if you build it, they will come" rule is the so-called "the Field of Dreams hypothesis" [1]. If a species make settlement decisions based on structural cues, then this rule can be used in conservation of its population. However, as described in the previous sections of this review, birds can choose breeding sites in many different ways, e.g., based on social information, instead of direct sampling of habitat patches. In such situations the researchers have to provide for individuals both appropriate habitat structure as well as the social environment which induce settlement in this habitat [1]. Even good-quality habitat may be unoccupied if it lacks settlement cues, based on which birds may assess its quality $[6,58]$. This happens due to perceptual errors that lead to an underestimation of the actual habitat 
resources [58]. Therefore, with the same enthusiasm scientists should protect habitat structure, as well as sources of information that allow birds to assess their quality and make decisions.

Manipulation of social information is considered as a potentially useful tool in the conservation of songbirds $[3,7,38,67,125,158]$. Especially great potential may have manipulation of location cues, because of the easy application and low cost of this method. Ahlering et al. [3] reviewed papers on conspecific attraction in context of conservation of migratory songbirds. Yet this review extends it with recently published papers and focuses only on research with use of experimental approach (the correlative studies are excluded) (Table 1). Heterospecific cues can also be easily simulated in the environment [93], thus may be a potential tool in conservation biology as well. The review of heterospecific attraction in song birds' research is evaluated in Table 2. As in the case of conspecific attraction, only experimental studies were considered, because they represent a form of active protection methods and are suggested, in literature, as potentially highly effective tool in conservation biology.

So far, the results of 21 experiments on conspecific attraction for the 13 species of songbirds were published (Table 1). In 14 experiments birds were attracted to simulated cues and in 7 of them they colonized previously unoccupied sites (Table 1). Among the 13 species of songbirds for which the experiments were performed, only 3 species i.e., the American Redstart (Setophaga ruticilla), the Black-throated Blue Warbler (Dendroica caerulescens), and the Least Flycatcher were studied in more than one location (Table 1). In studies on the Least Flycatcher and the Black-throated Blue Warbler, researchers obtained different results depending on where the experiments were performed (Table 1). These inconsistencies demonstrate that in different locations in the range of distribution, the same species may use various strategies to decide where to settle, which has significant implications for conservation. Although using conspecific cues have been described in several species of songbirds, we do not know how widespread this phenomenon is, because most studies on conspecific attraction were performed in USA and only one paper relates to research conducted in Europe (Table 1). Hence, we need more research to accurately determine in how many species artificial simulation of conspecific cues can be considered as a conservation method.

Using heterospecific cues to make settlement decisions was tested for many songbird species (Table 2). However, in most cases researchers measured numerical response for entire groups (e.g., migrants, ground foragers, etc.), rather than for single species. Hence, it is impossible to compare the number of species tested with experiments on con- and heterospecific attraction. In most studies (9 out of 13), researchers demonstrated positive relationship between manipulated density of residents and species or group of species expected to use them as settlement cues (Table 2). Although a positive numerical response to the experimental manipulation was shown for entire breeding communities, we do not know how widespread is using heterospecific cues by songbirds. This is because the vast majority of studies were conducted only in Europe, mainly in Sweden and Finland (Table 2). Hence, more research is needed to actually assess which species, where, and under what environmental conditions make settlement decisions based on heterospecific cues.

Breeding Success, Non-Target Effects, and Long-Term Effects: Urgent Research Needs for Conservation and Management

If the manipulation of location cues should be an effective tool in conservation and management, birds have to not only settle in a particular habitat patch, but also successfully breed and return to it in the following year. Unfortunately, little is known about the breeding success and site fidelity after the cessation of manipulation in birds, which were experimentally tested for the use of location cues. Considering experiments on both con- and heterospecific attraction, results about reproductive success of individuals were reported in only 6 cases and are inconsistent (Table 1, 2). Moreover, Betts et al. [8] provided some alarming results, showed that by using manipulation of social cues scientists are able to introduce birds to the suboptimal habitat patches where they normally do not occur. If birds will be attracted to such habitat patches, we can expect that their breeding success will be lower than if they do not respond to manipulation. Thus, artificial-attraction methods provide a risk of creating ecological traps, in which songbird populations will not be able to function [6]. Moreover, an important issue is the effect of these methods on other community members [3]. There are only two experiments' results available, in which researchers investigated these non-target effects when using artificialattraction methods. Betts et al. [9] described that the Blackthroated Blue Warblers settled in previously unoccupied habitat patches in response to playback manipulation, and this resulted in the abandonment of this habitat for 3 of the 4 other species for which changes in abundance were analyzed. By providing the Least Flycatcher' vocal cues on selected plots, Fletcher [41] showed that this manipulation reduced species richness of migratory birds, e.g., the Song Sparrow (Melospiza melodia), American Goldfinch (Carduelis tristis), and Northern Waterthrush (Seiurus noveboracensis) by $\sim 30 \%$. Considering the results of these two studies, there is a reasonable risk that manipulation of 
social cues may involve some non-target effects, e.g., general decline in species diversity on experimental plots due to interspecific avoidance. Furthermore, Fletcher [41] and Betts et al. [9] studied only numerical response of nontarget species on playback experiments. However, we cannot exclude the possibility that some species did not decline in numbers (or decline slightly), but had a lower breeding success, e.g., due to increased competition. Then, assessing only numerical response may not reveal some negative effects of artificial-attraction methods on other species. Hence, in addition to assessing breeding success of cue-users, it is important to take into account the complex impact of artificial-attraction methods on other species in the community.

Simulation of location cues should be a self-reinforcing mechanism. This means that birds should be attracted to habitat patches with artificial cues, breed there successfully, and return to these patches in subsequent years, after the cessation of manipulation. Theoretically, successfully breeding individuals, which initially selected habitat patch based on location cues, may reverse their strategy and decide where to settle according to the win-stay:loseswitch rule (e.g., [119]) in the next seasons. However, due to lack of empirical data, we do not know how artificialattraction methods affect subsequent settlement decisions. In fact, only in the case of the Black-capped Vireo (Vireo atricapilla) which use conspecific cues, Ward and Schlossberg [158] described that birds return to previously manipulated sites and breed successfully (Table 1). Such long-term effect of location cues manipulation was not studied in the rest of experiments on conspecific as well as in any study on heterospecific attraction. Manipulation of resident densities has to be permanent between seasons, if this method is to be considered for the conservation of migratory songbirds. Assuming that provisioning of nest boxes and feeders is sufficient to hold stable densities of residents between breeding seasons (e.g., [146]), this effect can be sustained and achieved at low cost. However, if a stable residents' density requires removal of some individuals or their translocation among habitat patches (e.g., [94]), then this method may be expensive and difficult to implement, thus impractical for conservation and management.

Artificial-attraction methods should provide an opportunity for successful breeding for individuals and initiate the preference of this patch in the following years. Furthermore, it should not cause any negative non-target effects on the other community members. Without knowledge about reproductive success of cue-users, permanence of attraction and its effect on the other species, applying artificial-attraction methods in conservation is just a more sophisticated form of "Field of Dreams" rule.
How to Use Artificial-Attraction Methods in Practice?

Sometimes conservation cannot wait for science, because populations of many songbird species decline rapidly and highly effective methods to protect are in need [3]. Six things are crucial to consider, if manipulation of social information is planned to be used in conservation and management. (1) Target species: consider whether the species has features which may suggest that it is a potential cue-user. Ahlering et al. [3] described clues, which may suggest that particular species use conspecific cues (see Table 2 in [3]), e.g., migratory behavior, short breeding season, and aggregated distribution. However, similar features should characterize species that potentially use heterospecific cues as well. (2) Habitat preferences: recognize precisely the habitat requirements and preferences (e.g., vegetation type, minimal required patch area) of target species, before using manipulation of social cues to minimize the risk of unintentional creation of ecological traps. (3) Type of simulated cues: consider what kind of manipulation will be appropriate for a given species, whether you need to use playback and/or decoys. Timing of cue simulation (pre and/or post-breeding) should also be taken into account $[3,125]$, as well as technical characteristics of played back recordings [3, 154]. In songbirds with high geographical variation in song structure (e.g., song dialects) only recordings from local subpopulations should be used for playback simulations. (4) Short-time effect: assess not only numerical response on artificial cues, but also reproductive success of individuals [3]. This allows avoiding accidental creation of ecological traps in which populations cannot survive. (5) Long-time effect: monitor population abundance and individuals' breeding success after the cessation of manipulation. (6) Non-target effects: use artificial-attraction methods carefully and evaluate the effects of providing social cues on non-target species in community [3, 9, 41]. When using artificialattraction methods to conserve one species, researchers cannot lead to a decline in overall species diversity.

\section{Conclusions}

Habitat selection is a hierarchical decision-making process, in which acquiring and using information about habitat quality allows birds to reduce uncertainty. This knowledge may be obtained in various ways, e.g., by own experience or monitoring others' behavior. Wrong decisions may lead to dramatic consequences; therefore, birds have to constantly update the acquired information. Obtaining, using, updating, and sharing of information among individuals or species constitute the central element of habitat selection process. However, despite popularity of birds' habitat 
selection studies, still many fundamental mechanisms of these processes remain unexplained.

Below 5 areas of research are mentioned (except the applicative aspects described in the previous section), which in my opinion require more researchers' attention and further development. (1) Prevalence of the use of social information in habitat selection process - more data on how songbirds use different sources of social information when selecting habitat is needed. Especially valuable are studies on the same species but in different environmental conditions, i.e., in various locations within its breeding range. (2) Use of social information during migration-so far research on social information use focused primarily on making decisions on the breeding grounds. During migration, songbirds have to choose stopover sites and finally a wintering habitat. The role of social information in this process remains unknown (but see [5]). (3) Evaluation of the outcome of cue-providers and cue-users interactions-until now due to lack of data it is not possible to clearly assess whether these interactions are mutualistic, parasitic, or commensalistic and how the outcome of these interactions is affected by environmental conditions. To understand the nature of these interactions, an investigation of the economy of using social information in habitat selection process is needed. (4) Mechanisms of simultaneous use of different sources of information by the same individuals-some studies show that birds are able to use various sources of information simultaneously when making settlement decisions (e.g., [37, 112]). However, the researchers do not know how different types of information are combined with each other, e.g., what happens when individuals' own experience and social information are contradictory? (5) Relationship between frequency of extra-pair copulations and using the performance-based types of informationrecently, Campomizzi et al. [18] suggested that in the case of species with frequent extra-pair copulations, individuals in nearby territories acquire information about own, rather than neighbors' breeding success. Thus, they may gather personal, not public information as previously thought. Perhaps, all published examples of the use of public information should be reconsidered in regard to frequency of extra-pair copulations in a particular species. Moreover, this hypothesis leads to intriguing question [18]: because copulations may not result in fertilizations, what cue is used by individuals to assess their reproductive success from extrapair copulations?

The role of this review was to summarize some aspects of the habitat selection process in songbirds, considering it as a decision-making process in which the key role is played by information. During their life, individuals every day are faced with uncertainty. To effectively reduce it, they have to acquire information, which makes their world more predictable and allows making appropriate decisions.
The phenomenon of acquiring, using, updating, and sharing information by individuals constitutes a fascinating field of research in which a number of key questions still remains unanswered. If this review reduced the uncertainty about how the scientists' world understands and perceives the habitat selection process in songbirds, there might be a chance to finally untangle this phenomenon.

Acknowledgments I am grateful to L. Kuczyński for many valuable comments and inspiring discussions. I thank two anonymous reviewers and N. Królikowska for comments which improved the manuscript. I thank P. Malińska for improving the English.

\section{References}

1. Ahlering MA, Faaborg J (2006) Avian habitat management meets conspecific attraction: if you build it, will they come? Auk 123(2):301-312

2. Ahlering MA, Johnson DH, Faaborg J (2006) Conspecific attraction in a grassland bird, the Baird's Sparrow. J Field Ornithol 77(4):365-371

3. Ahlering MA, Arlt D, Betts MG, Fletcher RJ, Nocera JJ, Ward MP (2010) Research needs and recommendations for the use of conspecific-attraction methods in the conservation of migratory songbirds. Condor 112(2):252-264

4. Alatalo RV, Lindberg A, Björklund M (1982) Can the song of male birds attract other males? An experiment with the pied flycatcher Ficedula hypoleuca. Bird Behav 4(1):42-45

5. Alessi MG, Benson TJ, Ward MP (2010) Nocturnal social cues attract migrating Yellow-breasted Chats. Wilson J Ornithol 122(4):780-783

6. Battin J (2004) When good animals love bad habitats: ecological traps and the conservation of animal populations. Conserv Biol 18(6):1482-1491

7. Bayard TS, Elphick CS (2012) Testing for conspecific attraction in an obligate saltmarsh bird: can behavior be used to aid marsh restoration? Wetlands 32(3):521-529

8. Betts MG, Hadley AS, Rodenhouse N, Nocera JJ (2008) Social information trumps vegetation structure in breeding-site selection by a migrant songbird. Proc R Soc B 275(1648):2257-2263

9. Betts MG, Nocera JJ, Hadley AS (2010) Settlement in novel habitats induced by social information may disrupt community structure. Condor 112(2):265-273

10. Bikhchandani S, Hirshleifer D, Welch I (1992) A theory of fads, fashion, custom, and cultural changes as informational cascades. J Polit Econ 100(5):992-1026

11. Block WM, Brennan LA (1993) The habitat concept in ornithology: theory and applications. Curr Ornithol 11:35-91

12. Bollinger EK, Gavin TA (1989) The effects of site quality on breeding-site fidelity in Bobolinks. Auk 106(4):584-594

13. Boulinier T, Danchin E (1997) The use of conspecific reproductive success for breeding patch selection in terrestrial migratory species. Evol Ecol 11(5):505-517

14. Boulinier T, Danchin E, Monnat JY, Doutrelant C, Cadiou B (1996) Timing of prospecting and the value of information in a colonial breeding bird. J Avian Biol 27(3):252-256

15. Boulinier T, McCoy KD, Sorci G (2001) Dispersal and parasitism. In: Clobert J, Danchin E, Dhondt AA, Nichols JD (eds) Dispersal. Oxford University Press, Oxford, pp 169-179

16. Brown CR, Brown MB (1996) Coloniality in the cliff swallow. The effect of group size on social behavior. University of Chicago Press, Chicago 
17. Campomizzi AJ, Butcher EA, Farrell SL, Snelgrove AG, Collier BA, Gutzwiller KJ, Morrison ML, Neal Wilkins R (2008) Conspecific attraction is a missing component in wildlife habitat modeling. J Wildl Manage 72(1):331-336

18. Campomizzi AJ, Morrison ML, DeWoody JA, Farrell SL, Neal Wilkins R (2012) Win-stay, lose-switch and public information strategies for patch fidelity of songbirds with rare extra-pair paternity. Sci Rep. doi:10.1038/srep00294

19. Candolin U (2003) The use of multiple cues in mate choice. Biol Rev Camb Philos Soc 78(4):575-595

20. Catchpole CK, Slater PJP (2008) Bird song: biological themes and variations. Cambridge University Press, New York

21. Clobert J, Danchin E, Dhondt AA, Nichols J (2001) Dispersal. Oxford University Press, Oxford

22. Cody ML (1985) Habitat selection in birds. Academic Press, New York

23. Cornell KL, Donovan TM (2010) Scale-dependent mechanisms of habitat selection for a migratory passerine: an experimental approach. Auk 127(4):899-908

24. Courter JR, Ritchison G (2010) Alarm calls of tufted titmice convey information about predator size and threat. Behav Ecol 21(5):936-942

25. Dall SRX, Giraldeau LA, Olsson O, McNamara JM, Stephens DW (2005) Information and its use by animals in evolutionary ecology. Trends Ecol Evol 20(4):187-193

26. Danchin E, Wagner RH (1997) The evolution of coloniality: the emergence of new perspectives. Trends Ecol Evol 12(9):342-347

27. Danchin E, Boulinier T, Massot M (1998) Conspecific reproductive success and breeding habitat selection: implications for the study of coloniality. Ecology 79(7):2415-2428

28. Danchin E, Heg D, Doligez B (2001) Public information and breeding habitat selection. In: Clobert J, Danchin E, Dhondt AA, Nichols JD (eds) Dispersal. Oxford University Press, Oxford, pp 243-258

29. Danchin E, Giraldeau LA, Valone TJ, Wagner RH (2004) Public Information: from nosy neighbors to cultural evolution. Science 305(5683):487-491

30. Dolby AS, Grubb TC Jr (1998) Benefits to satellite members in mixed species foraging groups: an experimental analysis. Anim Behav 56(2):501-509

31. Dolby AS, Grubb TC Jr (2000) Social context affects risk taking by a satellite species in a mixed-species foraging group. Behav Ecol 11(1):110-114

32. Doligez B, Boulinier T (2008) Habitat selection and habitat suitability preferences. In: Jørgensen SE, Fath BD (eds) Encyclopedia of ecology. Elsevier, Oxford, pp 1810-1830

33. Doligez B, Danchin E, Clobert J (2002) Public information and breeding habitat selection in a wild bird population. Science 297(5584):1070-1168

34. Doligez B, Cadet C, Danchin E, Boulinier T (2003) When to use public information for breeding habitat selection? The role of environmental predictability and density dependence. Anim Behav 66(5):973-988

35. Doligez B, Pärt T, Danchin E (2004) Prospecting in the collared flycatcher: gathering public information for future breeding habitat selection? Anim Behav 67(3):457-466

36. Doligez B, Pärt T, Danchin E, Clobert J, Gustafsson L (2004) Availability and use of public information and conspecific density for settlement decisions in the collared flycatcher. J Anim Ecol 73(1):75-87

37. Drilling NE, Thompson CF (1988) Natal and breeding dispersal in House Wrens (Troglodytes aedon). Auk 105(3):480-491

38. Farrell SL, Morrison ML, Campomizzi AJ, Neal Wilkins R (2012) Conspecific cues and breeding habitat selection in an endangered woodland warbler. J Anim Ecol 81(5):1056-1064
39. Fletcher RJ (2006) Emergent properties of conspecific attraction in fragmented landscapes. Am Nat 168(2):207-219

40. Fletcher RJ (2007) Species interactions and population density mediate the use of social cues for habitat selection. J Anim Ecol 76(3):598-606

41. Fletcher RJ (2008) Social information and community dynamics: nontarget effects from simulating social cues for management. Ecol Appl 18(7):1764-1773

42. Fletcher RJ (2009) Does attraction to conspecifics explain the patch-size effect? An experimental test. Oikos 118(8):1139-1147

43. Fletcher RJ, Sieving K (2010) Social-information use in heterogeneous landscapes: a prospectus. Condor 112(2):225-234

44. Formica VA, Gonser RA, Ramsay SM, Tuttle ME (2004) Spatial dynamics of alternative reproductive strategies: the role of neighbors. Ecology 85(4):1125-1136

45. Forsman JT, Martin TE (2009) Habitat selection for parasitefree space by hosts of parasitic cowbirds. Oikos 118(3):464-470

46. Forsman JT, Mönkkönen M (2001) Responses by breeding birds to heterospecific song and mobbing calls under varying predation risk. Anim Behav 62(6):1067-1073

47. Forsman JT, Thomson RL (2008) Evidence of information collection from heterospecifics in cavity-nesting birds. Ibis 150(2):409-412

48. Forsman JT, Mönkkönen M, Helle P, Inkeröinen J (1998) Heterospecifc attraction and food resources in migrants' breeding patch selection in northern boreal forest. Oecologia 115(1):278-286

49. Forsman JT, Seppänen JT, Mönkkönen M (2002) Positive fitness consequences of interspecific interaction with a potential competitor. Proc R Soc B 269(1500):1619-1623

50. Forsman JT, Thomson RL, Seppänen JT (2007) Mechanisms and fitness effects of interspecific information use between migrant and resident birds. Behav Ecol 18(5):888-894

51. Forsman JT, Hjernquist MB, Taipale J, Gustafsson L (2008) Competitor density cues for habitat quality facilitating habitat selection and investment decisions. Behav Ecol 19(3):539-545

52. Forsman JT, Hjernquist MB, Gustafsson L (2009) Experimental evidence for the use of density based interspecific social information in forest birds. Ecography 32(3):539-545

53. Forsman JT, Seppänen JT, Nykänen IL (2012) Observed heterospecific clutch size can affect offspring investment decisions. Biol Lett 8(3):341-343

54. Forsman JT, Mönkkönen M, Korpimäki E, Thomson RL (2013) Mammalian nest predator feces as a cue in avian habitat selection decisions. Behav Ecol 24(1):262-266

55. Fretwell SD, Lucas L (1970) On territorial behavior and other factors influencing habitat distributions of birds. Acta Biotheor 19(1):16-36

56. Fuller R (2012) Birds and habitat: relationships in changing landscapes. Cambridge University Press, Cambridge

57. Gavin TA, Bollinger EK (1988) Reproductive correlates of breeding-site fidelity in Bobolinks (Dolichonyx oryzivorus). Ecology 69(1):96-103

58. Gilroy JJ, Sutherland WJ (2007) Beyond ecological traps: perceptual errors and undervalued resources. Trends Ecol Evol 22(7):351-356

59. Giraldeau LA, Valone TJ, Templeton J (2002) Potential disadvantages of using socially acquired information. Philos Trans $\mathrm{R}$ Soc B 357(1427):1559-1566

60. Goodale E, Beauchamp G, Magrath RD, Nieh JC, Ruxton GD (2010) Interspecific information transfer influences animal community structure. Trend Ecol Evol 25(6):354-361

61. Green E, Lyon BE, Muehter VR, Ratcliffe LM, Oliver SJ, Boag PT (2000) Disruptive sexual selection for plumage coloration in a passerine bird. Nature 407(6807):1000-1003 
62. Greenwood PJ, Harvey PH (1982) The natal and breeding dispersal of birds. Annu Rev Ecol Evol Syst 13:1-21

63. Guilford T, Dawkins MS (1991) Receiver psychology and the evolution of animal signals. Anim Behav 42(1):1-14

64. Gustafsson L (1988) Inter- and intraspecific competition for nest holes in a population of the collared flycather Ficedula albicollis. Ibis 130(1):11-16

65. Haas CA (1998) Effects of prior nesting success on site fidelity and breeding dispersal: an experimental approach. Auk 115(4):929-936

66. Hahn BA, Silverman ED (2006) Social cues facilitate habitat selection: American redstarts establish breeding territories in response to song. Biol Lett 2(3):337-340

67. Hahn BA, Silverman ED (2007) Managing breeding forest songbirds with conspecific song playbacks. Anim Conserv 10(4):436-441

68. Harrap S, Quinn D (1995) Chickadees, tits, nuthatches and treecreepers. Princeton University Press, Princeton

69. Harrison ML, Green DJ, Krannitz PG (2009) Conspecifics influence the settlement decisions of male Brewer's Sparrows at the northern edge of their range. Condor 111(4):722-729

70. Hebets EA, Papaj DR (2005) Complex signal function: developing a framework of testable hypotheses. Behav Ecol Sociobiol 57(3):197-214

71. Hildén O (1965) Habitat selection in birds: a review. Ann Zool Fenn 2:53-75

72. Hromada M, Antczak M, Valone TJ, Tryjanowski P (2008) Settling decisions and heterospecific social information use in shrikes. PLoS ONE 3(12):e3930

73. Hurd CR (1996) Interspecific attraction to the mobbing calls of black capped chickadees (Parus atricapillus). Behav Ecol Sociobiol 38:287-292

74. Ioannou CC, Krause J (2008) Searching for prey: the effects of group size and number. Anim Behav 75(4):1383-1388

75. Jablonka E (2002) Information: its interpretation, its inheritance and its sharing. Philos Sci 69(4):578-605

76. Johnson MD (2007) Measuring habitat quality: a review. Condor 109(3):489-504

77. Johnstone RA (1996) Multiple displays in animal communication: 'backup signals' and 'multiple messages'. Philos Trans R Soc Lond 351(1337):329-338

78. Jones J (2001) Habitat selection studies in avian ecology: a critical review. Auk 118(2):557-562

79. Krause J, Godin JGJ (1995) Predator preferences for attacking particular prey group sizes-consequences for predator hunting success and prey predation risk. Anim Behav 50(2):465-473

80. Krebs JR (1977) The significance of song repertoires: the Beau Geste hypothesis. Anim Behav 25(2):475-478

81. Krebs JR, Ashcroft R, Webber MI (1978) Song repertoires and territory defence. Nature 271(5645):539-542

82. Loukola OJ, Seppänen JT, Forsman JT (2012) Intraspeci fic social information use in the selection of nest site characteristics. Anim Behav 83(3):629-633

83. Magrath RD, Pitcher BJ, Gardner JL (2009) An avian eavesdropping network: alarm signal reliability and heterospecific response. Behav Ecol 20(4):745-752

84. Mariette MM, Griffith SC (2012) Conspecific attraction and nest site selection in a nomadic species, the zebra finch. Oikos 121(6):823-834

85. Martin TE (1993) Nest predation and nest sites: new perspectives on old patterns. Bioscience 43(8):523-532

86. Martin PR, Martin TE (2001) Behavioral interactions between coexisting species: song playback experiments with wood warblers. Ecology 82(1):207-218

87. Martin TE, Roper JR (1988) Nest predation and nest-site selection of a western population of the hermit thrush. Condor 90(1):51-57
88. Maynard Smith J (2000) The concept of information in biology. Philos Sci 67(2):177-194

89. McGregor PK, Krebs JR (1984) Sound degradation as a distance cue in great tit (Parus major) song. Behav Ecol Sociobiol 16:49-56

90. Mennill DJ, Ratcliffe LM, Boag PT (2002) Female eavesdropping on male song contests in songbirds. Science 296:873

91. Mills LS, Soule ME, Doak DF (1993) The keystone-species concept in ecology and conservation. Bioscience 43(4):219-226

92. Mills AM, Rising JD, Jackson DA (2006) Conspecific attraction during establishment of Least Flycatcher clusters. J Field Ornithol 77(1):34-38

93. Mönkkönen M, Forsman JT (2002) Heterospecific attraction among forest birds: a review. Ornithol Sci 1:41-51

94. Mönkkönen M, Helle P, Soppela K (1990) Numerical and behavioural responses of migrant passerines to experimental manipulation of resident tits (Parus spp.): heterospecific attraction in northern breeding bird communities? Oecologia $85(2): 218-225$

95. Mönkkönen M, Forsman JT, Helle P (1996) Mixed-species foraging aggregations and heterospecific attraction in boreal bird communities. Oikos 77(1):127-136

96. Mönkkönen M, Helle P, Niemi G, Montgomery K (1997) Heterospecific attraction affects community structure and migrant abundances in northern breeding bird communities. Can J Zool 75(12):2077-2083

97. Mönkkönen M, Härdling R, Forsman JT, Tuomi J (1999) Evolution of heterospecific attraction: using other species as cues in habitat selection. Evol Ecol 13(1):91-104

98. Morand-Ferron J, Doligez B, Dall SRX, Reader SM (2010) Social information use. In: Breed MD, Moore J (eds) Encyclopedia of animal behavior. Academic Press, Oxford, Oxford, pp 242-250

99. Morosinotto C, Thomson RL, Korpimäki E (2010) Habitat selection as an antipredator behaviour in a multi-predator landscape: all enemies are not equal. J Animl Ecol 79(2):327-333

100. Morris DW (2003) Toward an ecological synthesis: a case for habitat selection. Oecologia 136(1):1-13

101. Morton ES (1986) Predictions from the ranging hypothesis for the evolution of long distance signals in birds. Behaviour 99:65-86

102. Naguib M (1995) Auditory distance assessment of singing conspecifics in Carolina wrens: the role of reverberation and frequency-dependent attenuation. Anim Behav 50(5):1297-1307

103. Nocera JJ, Betts MG (2010) The role of social information in avian habitat selection. Condor 112(2):222-224

104. Nocera JJ, Ratcliffe LM (2010) Migrant and resident birds adjust antipredator behavior in response to social information accuracy. Behav Ecol 21(1):121-128

105. Nocera JJ, Forbes GJ, Giraldeau LA (2006) Inadvertent social information in breeding site selection of natal dispersing birds. Proc R Soc B 273(1584):349-355

106. Nocera JJ, Forbes GJ, Giraldeau LA (2009) Aggregations from using inadvertent social information: a form of ideal habitat selection. Ecography 32(1):143-152

107. Oberweger K, Goller F (2001) The metabolic cost of birdsong production. J Exp Biol 204:3379-3385

108. Paine RT (1966) Food web complexity and species diversity. Am Nat 100(910):65-75

109. Paine RT (1969) A note on trophic complexity and community stability. Am Nat 103(929):91-93

110. Parejo D, Danchin E, Avilés JM (2005) The heterospecific habitat copying hypothesis: can competitors indicate habitat quality? Behav Ecol 16(1):96-105

111. Parejo D, Oro D, Danchin E (2006) Testing habitat copying in breeding habitat selection in a species adapted to variable environments. Ibis 148(1):146-154 
112. Parejo D, White J, Danchin E (2007) Settlement decisions in blue tits: difference in the use of social information according to age and individual success. Naturwissenschaften 94(9):749-757

113. Parejo D, Danchin E, Silva N, White JF, Dreiss AN, Avilés JM (2008) Do great tits rely on inadvertent social information from blue tits? A habitat selection experiment. Behav Ecol Sociobiol 62(10):1569-1579

114. Pärt T, Doligez B (2003) Gathering public information for habitat selection: prospecting birds cue on parental activity. Proc R Soc B 270(1526):1809-1813

115. Pärt T, Arlt D, Doligez B, Low M, Qvarnström A (2011) Prospectors combine social and environmental information to improve habitat selection and breeding success in the subsequent year. J Anim Ecol 80(6):1227-1235

116. Partan SR, Marler P (1999) Communication goes multimodal. Science 283(5406):1272-1273

117. Peak TM, Terry AMR, McGregor PK, Dabelsteen T (2002) Do great tits assess rivals by combining direct experience with information gathered by eavesdropping? Proc R Soc B Biol Sci 269(1503):1925-1929

118. Plotkin HC (1997) Darwin machines and the nature of knowledge. Harvard University Press, Cambridge

119. Porneluzi PA (2003) Prior breeding success affects return rates of territorial male Ovenbirds. Condor 105(1):73-79

120. Reed JM, Boulinier T, Danchin E, Oring LW (1999) Informed dispersal: prospecting by birds for breeding sites. Curr Ornithol 15:189-259

121. Reid ML (1987) Costliness and reliability in the singing vigour of Ipswich sparrows. Anim Behav 35(6):1735-1743

122. Rieucau G, Giraldeau LA (2011) Exploring the costs and benefits of social information use: an appraisal of current experimental evidence. Philos Trans R Soc B 366(1567):949957

123. Roberts G (1996) Why individual vigilance declines as group size increases. Anim Behav 51(5):1077-1086

124. Rowe C (1999) Receiver psychology and the evolution of multicomponent signals. Anim Behav 58(5):921-931

125. Schlossberg S, Ward MP (2004) Using conspecific attraction to conserve endangered birds. Endang Spec 21(4):132-138

126. Schmidt KA (2001) Site fidelity in habitats with contrasting levels of nest predation and brood parasitism. Evo Ecol Res 3(6):633-648

127. Schmidt KA (2004) Site fidelity in temporally correlated environments enhances population persistence. Ecol Lett 7(3):176-184

128. Schmidt KA, Dall SRX, van Glis JA (2010) The ecology of information: an overview on the ecological significance of making informed decisions. Oikos 119(2):304-316

129. Seppänen JT, Forsman JT (2007) Interspecific social learning: novel preference can be copied from a competing species. Curr Biol 17(14):1248-1252

130. Seppänen JT, Forsman JT, Mönkkönen M, Thomson RL (2007) Social information use is a process across time, space, and ecology, reaching heterospecifics. Ecology 88(7):1622-1633

131. Shannon CE, Weaver W (1949) The mathematical theory of communication. University of Illinois Press, Urbana

132. Sieving KE, Contreras TA, Maute KL (2004) Heterospecific facilitation of forest-boundar y crossing by mobbing understory birds in North-central Florida. Auk 121(3):738-751

133. Sieving KE, Hetrick SA, Aver y ML (2010) The versatility of graded acoustic measures in classification of predation threats by the tufted titmouse Baeolophus bicolor: exploring a mixed framework for threat communication. Oikos 119(2):264-276

134. Slagsvold T (1980) Habitat selection in birds: on the presence of other birds species with special regard to Turdus pilaris. J Anim Ecol 49(2):523-536
135. Smith RJ (1986) Evolution of alarm signals: role of benefits of retaining group members or territorial neighbors. Am Nat 128(4):604-609

136. Soard CM, Ritchison G (2009) 'Chick-a-dee' calls of Carolina chickadees convey information about degree of threat posed by avian predators. Anim Behav 78(6):1447-1453

137. Stamps JA (1987) Conspecifics as cues to territory quality: a preference of juvenile lizards (Anolis aeneus) for previously used territories. Am Nat 129(5):629-642

138. Stamps JA (1988) Conspecific attraction and aggregation in territorial species. Am Nat 131(3):329-347

139. Stamps JA (1991) The effects of conspecifics on habitat selection in territorial species. Behav Ecol Sociobiol 28(1):29-36

140. Tarof SA, Ratcliffe LM (2004) Habitat characteristics and nest predation do not explain clustered breeding in Least Flycatchers (Empidonax minimus). Auk 121(3):877-893

141. Tarof SA, Ratcliffe LM, Kasumovic MM, Boag PT (2005) Are least flycatcher (Empidonax minimus) clusters hidden leks? Behav Ecol 16(1):207-217

142. Templeton JJ, Giraldeau LA (1995) Patch assessment in foraging flocks of European starlings: evidence for the use of public information. Behav Ecol 6(1):65-72

143. Templeton CN, Greene E (2007) Nuthatches eavesdrop on variations in heterospecific chickadee mobbing alarm calls. Proc Natl Acad Sci 104(13):5479-5482

144. Templeton CN, Greene E, Davis K (2005) Allometry of alarm calls: black-capped chickadees encode information about predator size. Science 308:1934-1937

145. Thériault S, Villard MA, Haché S (2012) Habitat selection in site-faithful ovenbirds and recruits in the absence of experimental attraction. Behav Ecol. doi:10.1093/beheco/ars119

146. Thomson RL, Forsman JT, Mönkkönen M (2003) Positive interactions between migrant and resident birds: testing the heterospecific attraction hypothesis. Oecologia 134(3):431-438

147. Thomson RL, Tomás G, Forsman JT, Mönkkönen M (2012) Manipulating individual decisions and environmental conditions reveal individual quality in decision-making and non-lethal costs of predation risk. PLoS ONE 7(12):e52226

148. Timonen S, Mönkkönen M, Orell M (1994) Does competition with residents affect the distribution of migrant territories? Ornis Fennica 71(2):55-60

149. Turner GF, Pitcher TJ (1986) Attack abatement: a model for group protection by combined avoidance and dilution. Am Nat 128(2):228-240

150. Valone TJ (1989) Group foraging, public information, and patch estimation. Oikos 56(3):357-363

151. Valone TJ (2007) From eavesdropping on performance to copying the behavior of others: a review of public information use. Behav Ecol Sociobiol 62(1):1-14

152. Valone TJ, Templeton JJ (2002) Public information for the assessment of quality: a widespread social phenomenon. Philos Trans R Soc B 357(1427):1549-1557

153. Virkkala R (2006) Why we study woodpeckers? The significance of woodpeckers in forest ecosystems. Ann Zool Fenn 43:82-85

154. Virzi T, Boulton RL, Davis MJ, Gilroy JJ, Lockwood JJ (2012) Effectiveness of artificial song playback on influencing the settlement decisions of an endangered resident grassland passerine. Condor 114(4):846-855

155. Wagner RH, Danchin E (2003) Conspecific copying: a general mechanism of social aggregation. Anim Behav 65(2):405-408

156. Wagner RH, Danchin E (2010) A taxonomy of biological information. Oikos 119(2):203-209

157. Ward MP (2005) Habitat selection by dispersing yellow-headed blackbirds: evidence of prospecting and the use of public information. Oecologia 145(4):650-657 
158. Ward MP, Schlossberg S (2004) Conspecific attraction and the conservation of territorial songbirds. Conserv Biol 18(2):519-525

159. Ward S, Slater PJB (2005) Raised thermo-regulatory costs at exposed song posts increase the energetic cost of singing for willow warblers, Phylloscopus trochilus. J Avian Biol 36(4):280-286
160. Ward MP, Zahavi A (1973) The importance of certain assemblages of birds as "information-centres" for food-finding. Ibis 115(4):517-534

161. Ward MP, Benson TJ, Semel B, Herkert JR (2010) The use of social cues in habitat selection by wetland birds. Condor 112(2):245-251 